\title{
Agata Grabowska-Bacza
}

\section{PRAWA CZŁOWIEKA W CZASIE WOJNY}

\section{WSTĘP}

Według Jean Jeacquesa Babela, francuskiego historyka, w ciągu 5559 lat, od czasów Sumerów do II wojny światowej doszło do 14513 wojen ${ }^{1}$. Kiedy w 1945 roku zakończyła się II wojna światowa pokój na świecie nie zapanował. Wojny i konflikty zbrojne trwają do dzisiaj, giną ludzie, społeczność międzynarodowa nie zdołała utrzymać pokoju w XX wieku.

Kolejny wiek miał przynieść pokój, a tymczasem już w 2001 roku wstrząsnął światem Zamach terrorystyczny na World Trade Center. W tym samym roku NATO rozpoczęło wojnę w Afganistanie w celu obalenia rządów Talibów. W 2003 Stany Zjednoczone i kilka innych państw prowadziły drugą wojnę w Zatoce Perskiej, której skutkiem było wyzwolenie Iraku spod władzy Saddama Husajna. W 2004 roku na Ukrainie wybucha pomarańczowa rewolucja, w wyniku której władzę przejęła opozycja. Rok 2006 to II wojna libańska i wybuch wojny w Somalii, która trwała trzy lata. W 2008 w Tybecie doszło do zamieszek na tle politycznym. I w tym samym roku wybuchła wojna w Osetii Południowej. Od 2010 mówimy o Wiośnie Ludów Arabskich. Najpierw maiły miejsce protesty $\mathrm{w}$ krajach arabskich przeciwko dyktatorskim władzom (20102013), następnie wojna domowa w Libii (2011), potem wojna domowa w Syrii (2011-2013), trudna jest obecnie sytuacja w Egipcie.

Świat nie zaznał pokoju, w wielu jego zakątkach trwa wojna, często problemem w konfliktach zbrojnych jest uszanowanie praw człowieka, albo raczej ich nagminne łamanie. Oczywiście, że wojna niesie śmierć żołnierzom walczącym, ale i coraz częściej ludności cywilnej. Cierpią niewinni, zupełnie niepotrzebnie. Istnieje możliwość zmniejszenia albo nawet zniwelowania wielu cierpień, społeczność międzynarodowa stworzyła wiele rozwiązań prawnych, które niestety

1 Por. J. Borgosz, Drogi i bezdroża filozofii pokoju. (Od Homera do Jana Pawła II), Warszawa 1989, s. 7. 
nie są wdrażane w życie. Poniższe refleksje mają na celu ukazanie jednego z praw człowieka, prawa do życia (które umożliwia realizację pozostałych praw człowieka) w czasie wojny.

Żyjemy w kraju, na terenie którego nie trwa wojna i który aktualnie (stan na czerwiec 2013) nie jest $\mathrm{w}$ stanie wojny $\mathrm{z}$ innym krajem, ale polscy żołnierze z racji na misje ONZ, członkostwo Polski w NATO i UE biorą udział w działaniach zbrojnych w różnych miejscach na świecie. Problem wojny dotyka bezpośrednio wiele polskich rodzin, rodzin, w których ojcowie i matki służą Ojczyźnie, opuszczają rodziny i wykonują rozkazy z narażeniem życia, wielu z nich już nie wraca. Nie można zasadnie twierdzić, że problem wojny jest nieaktualny w dzisiejszej Polsce.

\section{Ustalenia Terminologiczne}

Warto na początku wskazać czym jest wojna. „Tradycyjnie określa się wojnę jako stan walki orężnej między państwami i jako przeciwstawienie stanu pokoju" ${ }^{2}$. Istnieje wiele definicji wojny, ponieważ można dostrzegać w niej różne aspekty: psychologiczny, społeczny, prawny, moralny ${ }^{3}$. Prawników najbardziej interesuje punkt widzenia prawa. „Wojna w sensie prawnym oznacza zerwanie między państwami stosunków pokojowych i przejście do stosunków wojennych, które charakteryzują się walką zbrojną i aktami wrogimi skierowanymi przeciwko drugiemu państwu. Dawniej stan wojny uważany był za dopuszczalny przez prawo, a tzw. ius ad bellum za atrybut suwerenności państwowej”4. Dzisiaj jest inaczej, a szczególnie ważne okazuje się dawne ius in bello, czyli międzynarodowe prawo humanitarne, zwracające uwagę na tzw. prawa człowieka. Wojna nie jest pożądana, państwa chcą utrzymywać z sobą pokojowe stosunki. Wyrazem tych chęci są międzynarodowe organizacje, w ramach których podejmowane są liczne wysiłki, aby cała społeczności międzynarodowa żyła w pokoju.

Współcześnie za podstawę sprawiedliwego porządku prawnego, politycznego i społecznego są uznawane prawa człowieka ${ }^{5}$. Idea praw człowieka, która zyskała powszechną akceptację wpływa na politykę międzynarodową. Kiedyś taką ideą były idea prawa naturalnego, czy idea umowy społecznej, idea rozdzia-

2 R. Bierzanek, J. Symonides, Prawo międzynarodowe publiczne, Warszawa 2009, s. 379.

3 Por. Q. Wright, Wstęp [w:] Wojna $w$ dziejach Europy, red. M. Howard, Wrocław 1990, s. 5.

4 W. Góralczyk, S. Sawicki, Prawo międzynarodowe publiczne z zarysie, Warszawa 2009, s. 417.

5 Por. K. Stępień, Antropologiczno - metafizyczne podstawy praw człowieka, [w:] O prawach człowieka nieco inaczej, red. R. Monia, A. Kobyliński, Warszawa 2011, s. 63. 
łu władz. Teraz od ponad pół wieku funkcję taką pełnią prawa człowieka ${ }^{6}$. Są one najczęściej rozumiane jako powszechne, przyrodzone, niezbywalne, nienaruszalne i naturalne oraz niepodzielne prawa, przysługujące każdemu człowiekowi, a wynikające z godności osobowej. „Wypływają z samej natury człowieka, a nie z (...) ustaleń prawa międzynarodowego" ". Są ontycznie i antropologicznie uwarunkowane. „Poszczególne właściwości człowieka są podstawą treści poszczególnych praw chroniących lub rozwijających byt ludzki w rozmaitych jego aspektach i w różnych dziedzinach aktywności.(...) Ostateczną ontyczną podstawa wszystkich praw jest godność"8. Mowa o godności osobowej, ugruntowanej w byciu człowiekiem. Ta godność to „zespół cech, wyróżniających człowieka od innych stworzeń i zapewniająca mu centralne miejsce we wszechświecie"9.

Kategoria godności stanowi uzasadnienie i źródło praw człowieka. Jak zauważa profesor Zajadło „związek pomiędzy prawami i godnością człowieka stał się na tyle immanentny, że nie pozwala na automatyczną eliminację tego ostatniego pojęcia z tekstów normatywnych"10. Godność uznaje za cel, godność zatem powinna być rozwijana ${ }^{11}$. Wspomina o niej już Karta Narodów Zjednoczonych z 1945 w Preambule: „My, Ludy Narodów Zjednoczonych, zdecydowane - uchronić przyszłe pokolenia od klęsk wojny, która dwukrotnie za naszego życia wyrządził a ludzkości niewypowiedziane cierpienia, - przywrócić wiarę w podstawowe prawa człowieka, w godność i wartość człowieka, w równouprawnienie mężczyzn i kobiet, w równość narodów dużych i małych(...) postanowiliśmy zjednoczyć nasze wysiłki dla wypełnienia tych zadań (...)”. Narody Zjednoczone tworzą Kartę, pamiętając okrucieństwo dwóch wojen światowych, pragną pokoju. Wskazują na wartość osoby, na godność osoby i konieczność szanowania człowieka i jego praw.

Karta nie formułuje żadnego katalogu praw, co zawarte jest w Powszechnej Deklaracji Praw Człowieka z 1948 roku. Jej Preambuła dokładniej mówi o prawach człowieka, ale również odnosi się do kategorii godności: „Zważywszy, że uznanie przyrodzonej godności oraz równych i niezbywalnych praw wszystkich członków wspólnoty ludzkiej jest podstawą wolności, sprawiedliwości i poko-

6 Zob. V. Posenti, Teraźniejszość i przyszłość praw człowieka, „Społeczeństwo” 2003, nr 1, s. 43.

7 J. Seifert, Antropologia praw człowieka, „Ethos” 12 (1999), nr 1-2, s. 137.

8 M. Piechowiak, Filozofia praw człowieka, Lublin 1999, s. 372.

9 K. Motyka, Wprowadzenie, [w:] Prawa człowieka. Wybór źródeł, red. K. Motyka, Lublin 2001, s. 29.

10 J. Zajadło, Godność jednostki w aktach prawa międzynarodowej ochrony praw człowieka, „Ruch prawniczy, ekonomiczny i socjologiczny, 1995, nr 3, s. 106.

11 Ibidem, s. 109. 
ju świata, zważywszy, że nieposzanowanie i nieprzestrzeganie praw człowieka doprowadziło do aktów barbarzyństwa, które wstrząsnęły sumieniem ludzkości, i że ogłoszono uroczyście jako najwznioślejszy cel ludzkości dążenie do zbudowania takiego świata, w którym ludzie korzystać będą z wolności słowa i przekonań oraz z wolności od strachu i nędzy, zważywszy, że konieczne jest zawarowanie praw człowieka przepisami prawa, aby nie musiał doprowadzony do ostateczności uciekać się do buntu przeciw tyranii i uciskowi, zważywszy, że, są konieczne jest popieranie rozwoju przyjaznych stosunków między narodami, zważywszy, że Narody Zjednoczone przywróciły swą wiarę w podstawowe prawa człowieka, godność i wartość jednostki oraz w równouprawnienie mężczyzn i kobiet, oraz wyraziły swe zdecydowanie popierania postępu społecznego i poprawy warunków życia w większej wolności, (...) Przeto Zgromadzenie Ogólne ogłasza uroczyście niniejszą Powszechną Deklarację Praw Człowieka jako wspólny najwyższy cel wszystkich ludów i wszystkich narodów, aby wszyscy ludzie i wszystkie organy społeczeństwa mając stale w pamięci niniejszą Deklarację dążyły w drodze nauczania i wychowywania do rozwijania poszanowania tych praw i wolności i aby zapewniły za pomocą postępowych środków o zasięgu krajowym i międzynarodowym powszechne i skuteczne uznanie i stosowanie tej Deklaracji zarówno wśród Państw Członkowskich, jak i wśród narodów zamieszkujących obszary podległe ich władzy" ${ }^{12}$. Dokładnie zostało uzasadnione dlaczego chcą szanować człowieka i jego prawa, wskazują na sprawiedliwość, wolność i na pokój, te wartości są ważne i Narody Zjednoczone mają nadzieję, że poszanowanie ich zapobiegnie okrucieństwu wojny. Pokój jest celem nadrzędnym, do którego dążyć będą poszczególne państwa osobno i wspólnie, państwa mają obowiązek stosować Deklarację, nauczać i wychowywać do szacunku wobec praw człowieka.

Powszechna Deklaracja Praw Człowieka nie jest jedynym dokumentem, który wspomina o prawach człowieka wynikających z godności, podobnie pakty. Preambuła Międzynarodowego Paktu Praw Obywatelskich i Politycznych ${ }^{13}$ stanowi: „Państwa-Strony niniejszego Paktu, zważywszy, że zgodnie z zasadami ogłoszonymi w Karcie Narodów Zjednoczonych uznani przyrodzonej godności oraz równych i niezbywalnych praw wszystkich członków wspólnoty ludzkiej stanowi podstawę wolności, sprawiedliwości i pokoju na świecie, uznając, że prawa te wynikają z przyrodzonej godności osoby ludzkiej, (...) zważywszy wynikający z Karty Narodów Zjednoczonych obowiązek Państw popierania powszechnego poszanowania i przestrzegania praw i wolności człowieka, biorąc

12 http://www.unesco.pl/fileadmin/user_upload/pdf/Powszechna_Deklaracja_Praw_ Czlowieka.pdf, (16.06.2013 r.).

13 Dz. U. z 1977 r. Nr 38, poz. 167. 
pod uwagę, że jednostka ludzka, mająca obowiązki w stosunku do innych jednostek i w stosunku do społeczności, do której należy, powinna dążyć do popierania i przestrzegania praw uznanych w niniejszym Pakcie, zgodziły się na następujące artykuły”. W pakcie odwołując się do Karty godność uznana jest za podstawę sprawiedliwości, wolności i pokoju. Celem poszanowania praw człowieka jest jego godne życie w pokoju.

Prawa człowieka są wymienione w wielu dokumentach, również w Międzynarodowym Pakcie Praw Gospodarczych, Społecznych i Kulturalnych z 1966 roku. „Państwa Strony niniejszego Paktu, zważywszy, że zgodnie z zasadami ogłoszonymi w Karcie Narodów Zjednoczonych uznanie przyrodzonej godności oraz równych i niezbywalnych praw wszystkich członków wspólnoty ludzkiej stanowi podstawę wolności, sprawiedliwości i pokoju na świecie, uznając, że prawa te wynikają z przyrodzonej godności człowieka, uznając, że zgodnie z Powszechną Deklaracją Praw Człowieka ideał wolnej istoty ludzkiej wyzwolonej od lęku i niedostatku może być osiągnięty tylko wówczas, kiedy zostaną stworzone warunki zapewniające każdemu korzystanie z praw gospodarczych, społecznych i kulturalnych oraz z praw obywatelskich i politycznych, zważywszy wynikający z Karty Narodów Zjednoczonych obowiązek Państw popierania powszechnego poszanowania i przestrzegania praw i wolności człowieka, biorąc pod uwagę, że jednostka ludzka, mająca obowiązki w stosunku do innych jednostek i w stosunku do społeczności, do której należy, powinna dążyć do popierania i przestrzegania praw uznanych w niniejszym Pakcie, zgodziły się na następujące artykuły”. Człowiek będzie mógł w pełni korzystać z praw gospodarczych, społecznych i kulturalnych, obywatelskich i politycznych tylko w czasie pokoju.

Praw człowieka dzielimy za francuskim prawnikiem Karelem Vasakiem na trzy generacje, pierwsza $\mathrm{z}$ nich to klasyczne prawa człowieka, prawa podstawowe. Należą do nich: prawa związane z egzystencją fizyczną, tj. prawo do życia, wolności osobistej i bezpieczeństwa; prawa związane $z$ wolnością światopoglądu, tj. wolność wyznania, sumienia, religii, myśli, wyrażania poglądów oraz prawa związane z egzystencją prawną, np. prawo do osobowości prawnej, ochrony prawnej w postępowaniu sądowym i prawa polityczne lub obywatelskie. Prawa drugiej generacji to prawa ekonomiczne, prawa socjalne, prawa kulturalne, prawo do zdrowia, edukacji (nauki), pracy. Prawami trzeciej generacji są: prawo narodów do samostanowienia politycznego, prawo do rozwoju, prawa ludów wobec wspólnot międzynarodowych, prawo ekonomiczne narodów do własnych zasobów i bogactw naturalnych, do zachowania kultury, środowiska naturalnego; prawa mniejszości narodowych i etnicznych, m.in. do zachowania własnej tożsamości, w tym swojego języka, podtrzymywania własnej tradycji, do rozwoju własnej kultury, szkolnictwa, instytucji kulturalnych; prawo do pokoju; 
prawo do czystego środowiska naturalnego oraz prawo do wspólnego dziedzictwa przeszłości, prawo do pomocy humanitarnej.

W kontekście praw człowieka mówimy o wojnie legalnej, o wojnie sprawiedliwej. David Luban powiązuje to następująco: „wojną sprawiedliwą jest wojna w obronie społecznie podstawowych praw człowieka (respektująca zasadę proporcjonalności) lub wojna w obronie własnej przed wojną niesprawiedliwą"14. Warto zauważyć, że „w niektórych sytuacjach cnota sprawiedliwości wymaga wykorzystania wojny jako prawomocnego i czasami koniecznego środka do osiągnięcia sprawiedliwego celu.(...) Wojna jest w pewnych sytuacjach aktem sprawiedliwym, kiedy prowadzona jest za pomocą właściwych środków i we właściwy sposób” ${ }^{15}$. Należy jednak ją uzasadnić. „Uzasadnienie, a zwłaszcza usprawiedliwienie wojny opiera się na zróżnicowanej argumentacji. Najczęściej są to przesłanki o charakterze pragmatycznym z odwołaniami do patriotyzmu, wolności, sprawiedliwości, słuszności i innych szlachetnych pojęć należących także do kategorii moralnych. (...) Z pojęciem wojny sprawiedliwej związane było przekonanie, że państwo ma prawo wszczynać wojnę tylko w sytuacji, gdy istnieje sprawiedliwa przyczyna i gdy powodu wojny w żaden inny sposób nie da się usunąć" ${ }^{16}$. Najlepiej żyć w pokoju, ale kiedy zachowanie pokoju nie jest możliwe, jeśli ktoś atakuje, trzeba się bronić. Jeżeli taka obrona jest uzasadniona oraz prowadzona we właściwy sposób, właściwymi sposobami nazywamy ją wojną legalną, czasem wojna legalna jest wojną sprawiedliwą. O tym, czy wojna jest legalna nie decydują poszczególne państwa w czasie trwania działań zbrojnych, prawo międzynarodowe ściśle wskazuje na przypadki, które można nazwać wojną legalną, o sytuacje, które można nazwać wojną sprawiedliwą trwa spór w nauce. Spór nierozstrzygalny, bo istniejący na gruncie uzasadnień etycznych.

\section{Dopuszczalność WoJnY We WspóŁCZesnym ŜWIECIE}

Nad bezpieczeństwem zbiorowym świata czuwać ma jeden $\mathrm{z}$ głównych organów ONZ - Rada Bezpieczeństwa. Odpowiada ona za utrzymanie międzynarodowego pokoju i bezpieczeństwa ${ }^{17}$. Podejmuje akcje w związku z zagrożeniem wojną, zakłóceniem pokoju i aktami agresji. Utrzymuje lub przywraca między-

14 D. Luban, Wojna sprawiedliwa a prawa człowieka, [w:] Etyka wojny. Antologia tekstów, red. T. Żuradzki, T. Kuniński, Warszawa 2009, s. 211.

15 M. Novak, Sprawiedliwy pokój i asymetryczne zagrożenie. Organizacja Narodów Zjednoczonych i obrona konieczna państwa „na nieznanym terenie”, „Etos,” 71-72 (2005), 150.

16 W. Łączkowski, Wojna, „Etos,” 71-72 (2005), s. 24.

17 Por. KNZ, art. 24. 
narodowy pokój ${ }^{18}$. Zgodnie z Preambuł a Karty i Deklaracją Narody zjednoczone za swój cel obierają życie w pokoju. Stąd istnienie i działanie Rady Bezpieczeństwa jest bardzo ważne dla całej społeczności międzynarodowej.

Sposoby działania Rady są dwa. Pierwszy jest pokojowy ${ }^{19}$. To pewne środki i procedury (takie jak: instrumenty dyplomacji prewencyjnej, procedury pokojowego załatwiania sporów, odpowiedni system ostrzegania, ograniczenie materialnych możliwości prowadzenia działań wojennych) oraz instytucje (dobrych usług, komisje badań, arbitrażu, sadownictwa rozjemczego ${ }^{20}$. Kiedy pokojowe środki są niewystarczające, może uciec się do drugiego sposobu, czyli użycia siły zbrojnej w celu przywrócenia pokoju. Wojna, której celem jest pokój. „Rada Bezpieczeństwa (...) jest władna podjąć taką akcję przy pomocy sił powietrznych, morskich lub lądowych, jaka mogłaby okazać się konieczną do utrzymania albo przywrócenia międzynarodowego pokoju i bezpieczeństwa. Akcja taka może polegać na demonstracjach, blokadzie i innych operacjach sił zbrojnych powietrznych, morskich lub lądowych członków Narodów Zjednoczonych"21. W celu obrony państwa można walczyć, ale tylko na wyraźne polecenie Rady.

Potwierdzone jest też na poziomie międzynarodowym, prawo państwa do suwerennego stanowienia o sobie i do wojny obronnej. Ale to prawo jest ograniczone. Przysługuje tylko państwu, które zostało napadnięte i tylko do czasu, aż Rada Bezpieczeństwa nie podejmie środków koniecznych do przywrócenia pokoju ${ }^{22}$. Gdyby Karta obowiązywała w 1939 Polska miałaby na gruncie tych przepisów prawo do legalnej wojny z III Rzeszą, od strony działań polskich wojna byłaby legalna.

Zatem mamy dwa możliwe przypadki wojny legalnej, jednak nie zawsze jest to równoznaczne $\mathrm{z}$ wojną sprawiedliwą, gdyż „tradycyjna teoria wojny sprawiedliwej obejmuje dwa zbiory zasad, z których jeden reguluje przystępowanie do wojny (ius ad bellum), drugi zaś jej prowadzenie (ius in bello) ${ }^{23}$.

18 Por. KNZ, art. 39.

19 Por. KNZ, art. 41.

20 Por. Konwencja haska o pokojowym załatwianiu sporów międzynarodowych z 18 października 1907 roku, M. Flemming, Międzynarodowe prawo humanitarne konfliktów zbrojnych. Zbiór dokumentów, Warszawa 2003, s. 29; KNZ, nr 33-36.

$21 \mathrm{KNZ}$, art. 42.

22 Por. KNZ, art. 51.

23 J. McMahan, Etyka zabijania na wojnie [w:] T. Żuradzki, T. Kuniński, op.cit.., s. 101. 


\section{IUS IN BELLO}

Teoria środków prowadzenia wojny, ius in bello, czyli prawo w wojnie; to współcześnie międzynarodowe prawo humanitarne konfliktów zbrojnych, które formułuje trzy zasadnicze warunki prowadzenia działań zbrojnych: warunek minimalnej siły do osiągnięcia zamierzonego celu, warunek proporcjonalności środków, warunek zróżnicowania ${ }^{24}$. Warunek minimalnej siły obliguje do używania środków przemocy w każdych okolicznościach, tylko na tyle, na ile są one konieczne do osiągnięcia zamierzonego celu. Warunek proporcjonalności środków to kalkulacja niepożądanych i pożądanych konsekwencji działań wojennych. Wskazuje on na zależność dwóch rodzajów spodziewanych skutków wojny, aby był spełniony przeważać muszą konsekwencje pożądane dla strony konfliktu. To bardzo intuicyjne, korzyści muszą być większe niż straty. Ostatni warunek, to warunek zróżnicowania nakazuje skierować działania zbrojne, przemoc, tylko przeciwko walczącej stronie przeciwnej, tj. np. żołnierzom, partyzantom, agresorom. Osoby niebiorące udziału w działaniach wojennych nie mogą być celem ataku ${ }^{25}$. Warunki, zwłaszcza ich sformułowania stwarzają wiele możliwości interpretacyjnych, dlatego dość kazuistyczne prawo międzynarodowe wylicza jako zasady albo zwyczaje konkretne normy dotyczące ius in bello. Nie ma jednego aktu normatywnego, w którym są one zawarte, ale doktryna tworzy katalogi zasad międzynarodowego prawa humanitarnego, na podstawie wielu umów, konwencji, paktów i deklaracji państw.

Prawo międzynarodowe zna zasady, których stosowanie ma na celu respektowanie godności każdego człowieka, również tego, który bierze udział w działaniach zbrojnych albo żyje w kraju, w którym toczą się te działania. Warto wskazać na wybrane zasady ${ }^{26}$, które mają za zadanie chronić społeczność międzynarodową. Zasada proporcjonalności w czasie ataku, niezdawania pardonu, zakazu zagarniania mienia, zakazu głodowania, nakaz humanitarności, zakaz różnicowania, zakaz zabójstw, tortur, kar cielesnych, eksperymentów medycznych, niewolnictwa, pracy przymusowej, kar zbiorowych, nakaz szanowania życia rodzinnego, mają za zadanie chronić przede wszystkim ludność cywilną, ale również walczących żołnierzy. Prawo humanitarne nakazuje udzielać pomocy medycznej rannym, chorym, szanować i grzebać zmarłych. Nakazuje również

24 Por. A. Zwoliński, Wojna sprawiedliwa?, "Ethos", 3-4 (2005), s. 64.

25 Por. Ibidem.

26 Autorem ich jest J.- M. Henckaerts, autor podaje w tłumaczeniu M. Szuniewicza za T.Jasudowicz (red.), Międzynarodowe prawo humanitarne we wspótczesnym świecie, Toruń, 2007, s. 219. 
godnie traktować osoby pozbawione wolności ${ }^{27}$. Należy zauważyć, że powyższe zasady nakazują respektowanie praw człowieka, zwłaszcza praw pierwszej generacji (prawo do życia ${ }^{28}$, prawo do wolności osobistej ${ }^{29}$, zakaz niewolnictwa i handlu ludźmi ${ }^{30}$, wolność od tortur ${ }^{31}$, wolność wyznania, sumienia, myśli ${ }^{32}$, wolność wypowiedzi ${ }^{33}$, równość wobec prawa ${ }^{34}$, prawo do osobowości prawnej ${ }^{35}$ ).

Międzynarodowy Pakt Praw Obywatelskich i Politycznych z 1966 roku, którego Preambuła była już wspominana formułuje wyraźnie zakaz zabijania, zakaz torturowania, zakaz niewolnictwa, zasada lex retro non agit, wolność myśli, sumienia i wyznania zawsze zachowują moc obowiązującą ${ }^{36}$. Zawsze, a zatem również w czasie wojny. $\mathrm{W}$ artykule 4 dopuszcza w wyjątkowych sytuacjach zagrożenia bezpieczeństwa publicznego (czyli w sytuacji wojny) zawieszenie stosowania zobowiązań paktu, czyli respektowania praw człowieka, ale nie wszystkich i formułuje tu warunki. Po pierwsze to musi być takie prawo człowieka, które może być zawieszone, artykuł wylicza te niezawieszalne przypadki. Po drugie należy respektować prawo międzynarodowe, postanowienia innych konwencji, po trzecie należy poinformować o takim fakcie Sekretarza Generalnego ONZ. Artykuł 4 stanowi:

„1. W przypadku gdy wyjątkowe niebezpieczeństwo publiczne zagraża istnieniu narodu i zostało ono urzędowo ogłoszone, Państwa-Strony niniejszego Paktu mogą podjąć kroki mające na celu zawieszenie stosowania zobowiązań wynikających z niniejszego Paktu w zakresie ściśle odpowiadającym wymogom sytuacji, pod warunkiem, że kroki te nie są sprzeczne $\mathrm{z}$ innymi ich zobowiązaniami wynikającymi z prawa międzynarodowego i nie pociągają za sobą dyskryminacji wyłącznie z powodu rasy, koloru skóry, płci, języka, religii lub pochodzenia społecznego. 2. Powyższe postanowienie nie upoważnia do zawieszenia stosowania postanowień artykułów 6, 7, 8 (ustępy 1 i 2), 11, 15, 16 i 18. 3. Każde z Państw-Stron niniejszego Paktu, korzystające z prawa do zawieszenia stosowania zobowiązań, poinformuje natychmiast pozostałe Państwa-Strony niniejszego Paktu, za pośrednictwem Sekretarza Generalnego Organizacji Narodów Zjednoczonych, jakie postanowienia Paktu zostały zawieszone oraz jakie były tego

27 Ibidem.

28 Por. Powszechna Deklaracja Praw Człowieka, art. 3.

29 Por. Ibidem.

30 Por. Ibidem, art. 4.

31 Por. Ibidem, art. 5.

32 Por. Ibidem, art. 18.

33 Por. Ibidem, art. 19.

34 Por. Ibidem, art. 7.

35 Por. Ibidem, art. 6.

36 Por. M.Flemming, Wstęp [w:] M. Flemming, op. cit., s. 20-21. 
powody. Następnie Państwo to zawiadomi tą samą drogą o terminie, w którym zawieszenie przestaje obowiązywać" .Najważniejsze prawo, prawo do życia jest jednak w pewnej mierze ograniczone, a mianowicie w czasie wojny za popełnienie najpoważniejszych przestępstw o charakterze wojskowym grozi kara śmierci, jeżeli państwo- strona zgłosiło takowe zastrzeżenie do Drugiego Protokołu Fakultatywnego do Międzynarodowego Paktu Praw Obywatelskich i Politycznych w sprawie zniesienia kary śmierci, na podstawie art. 2 rzeczonego Protokołu.

Prawa gospodarcze, społeczne i kulturalne nie maja takiego statusu jak obywatelskie i polityczne, mogą być zawieszone. Artykuł 4 Paktu Praw Gospodarczych, społecznych i kulturalnych stanowi: „Państwa Strony niniejszego Paktu uznają, że korzystanie z tych praw, zapewnione przez Państwo zgodnie z niniejszym Paktem, może być poddane przez Państwo tylko takim ograniczeniom, jakie przewiduje ustawa, i tylko $\mathrm{w}$ stopniu, $\mathrm{w}$ jakim jest to zgodne $\mathrm{z}$ istotą tych praw, oraz wy łącznie w celu popierania powszechnego dobrobytu w społeczeństwie demokratycznym". W praktyce oznacza to możliwość dowolnego zawieszania praw społecznych, gospodarczych i kulturalnych. Dlatego niezwykle ważne są pozostałe systemy ochrony praw człowieka.

$\mathrm{Na}$ koniec tych rozważań warto odnieść się do sytuacji w Polsce. Należy nadmienić, że na podstawie art. 233 Konstytucji RP niektóre prawa mogą być ograniczone, inne nie. „1.Ustawa określająca zakres ograniczeń wolności i praw człowieka i obywatela w czasie stanu wojennego i wyjątkowego nie może ograniczać wolności i praw określonych w art. 30 (godność człowieka), art. 34 i art. 36 (obywatelstwo), art. 38 (ochrona życia), art. 39, art. 40 i art. 41 ust. 4 (humanitarne traktowanie), art. 42 (ponoszenie odpowiedzialności karnej), art. 45 (dostęp do sądu), art. 47 (dobra osobiste), art. 53 (sumienie i religia), art. 63 (petycje) oraz art. 48 i art. 72 (rodzina i dziecko). 2.Niedopuszczalne jest ograniczenie wolności i praw człowieka i obywatela wyłącznie z powodu rasy, płci, języka, wyznania lub jego braku, pochodzenia społecznego, urodzenia oraz majątku. 3.Ustawa określająca zakres ograniczeń wolności i praw człowieka i obywatela w stanie klęski żywiołowej może ograniczać wolności i prawa określone w art. 22 (wolność działalności gospodarczej), art. 41 ust. 1, 3 i 5 (wolność osobista), art. 50 (nienaruszalność mieszkania), art. 52 ust. 1 (wolność poruszania się i pobytu na terytorium Rzeczypospolitej Polskiej), art. 59 ust. 3 (prawo do strajku), art. 64 (prawo własności), art. 65 ust. 1 (wolność pracy), art. 66 ust. 1 (prawo do bezpiecznych i higienicznych warunków pracy) oraz art. 66 ust. 2 (prawo do wypoczynku)". W każdym czasie, również w czasie wojny na terenie Rzeczpospolitej Polskiej szanowana jest godność każdego człowieka i wynikające z niej prawo do życia. Tego nie można zawiesić ani ograniczyć. W czasie wojny nadal obowiązuje artykuł trzydziesty i nadal każdy człowiek ma prawo do życia. Zawiesić albo 
ograniczyć można prawo gospodarcze, społeczne, kulturalne, ale nie prawo do życia. To prawo jest chronione przez polski system prawny, ale również poprzez inne systemy ponadpaństwowe.

Możemy mówić o czterech systemach ochrony praw człowieka, powszechnym, regionalnym, wewnątrzpaństwowym i pozarządowym. Wspomniane dokumenty ONZ i prawo międzynarodowe tworzą system powszechny, system pozarządowy tworzy przede wszystkim Czerwony Krzyż, w dziedzinie ius in bello warto wskazać Konwencje Genewskie z 1949 roku wraz z Protokołami dodatkowymi z 1977 roku. W kontekście prawa polskiego warto szczególną uwagę poświęcić systemom regionalnemu, tj. europejskiemu i wewnątrzpaństwowemu, tj. polskimi w aspekcie praw człowieka w czasie wojny. Niestety trzeba stwierdzić uczciwie, że żaden z systemów ochrony osobno, ani wszystkie razem nie sprawiają, by prawa człowieka były respektowane w czasie działań zbrojnych. Ale na pewno zmniejszają nagminność ich łamania.

\section{Europejskie Prawo Pokoju I Bezpieczeństwa A Prawa Czeowieka}

Wiele przepisów związanych z pokojem jest multiplikacją prawa międzynarodowego, które jak echo powtarza się w dokumentach Rady Europy, OBWE i UE.

„Europejskie prawo pokoju i bezpieczeństwa stanowi system obejmujący specyficzne normy, zasady, instytucje i procedury, odnoszące się do utrzymania i zapewnienia pokoju i bezpieczeństwa w Europie. Prawo to stanowi ochronę bezpieczeństwa zbiorowego i indywidualnego państw europejskich przed zagrożeniami zewnętrznymi i wewnętrznymi oraz służy zapewnieniu im pokojowych warunków rozwoju ich wzajemnych stosunków i uczestnictwa w obrocie międzynarodowym"37. Mówiąc o regionalnym systemie ochrony praw człowieka w kontekście wojny należy od tego zacząć. Tworzą go przede wszystkim OBWE, UE i Rada Europy, a Polska jest członkiem każdej z tych organizacji. W związku $\mathrm{z}$ tym jest też stroną umów międzynarodowych oraz adresatem aktów normatywnych, które zostaną poniżej opisane.

Akt Końcowy Konferencji Bezpieczeństwa i Współpracy w Europie z 1 sierpnia 1975 roku sformułował wśród zasad: suwerennej równości, życia w pokoju, nienaruszalności granic i integralności terytorialnej państw, oraz współpracy między państwami również zasadę poszanowania praw człowieka. „Państwa uczestniczące będą szanować prawa człowieka i podstawowe wolności, włącza-

37 L. Łukaszuk, A. Skowroński, Europejskie prawo pokoju i bezpieczeństwa. Materiały i komentarze, Warszawa 2003, s. 26. 
jąc w to wolność myśli, sumienia, religii lub przekonań Każdego bez względu na różnice rasy, płci, języka lub religii. (...) Państwa uczestniczące uznają powszechne znaczenie praw człowieka i podstawowych wolności, których poszanowanie jest istotnym czynnikiem pokoju, sprawiedliwości i dobrobytu, niezbędnych do zapewnienia rozwoju przyjaznych stosunków i współpracy miedzy nimi, jak również miedzy wszystkimi państwami(...)”. Pokój jest celem, do którego zdążają państwa OBWE, deklarując poszanowanie praw człowieka, w tym prawa do życia. Państwa zobowiązują się do przestrzegania prawa humanitarnego i do edukacji swoich obywateli w tym zakresie. Kodeks postępowania w aspektach polityczno - wojskowych bezpieczeństwa z 6 grudnia 1994 roku w artykułach 29 i 30 obliguje państwa do edukacji w dziedzinie prawa humanitarnego. Zarówno obywateli w jak najszerszym rozpowszechnianiu tego prawa, jak i członków sił zbrojnych w jak najczęstszym uwzględnianiu go w programach szkolenia i regulaminach ${ }^{38}$.

OBWE współtworzy europejski system m.in. z Unią Europejskąa ${ }^{39}$. Strategia bezpieczeństwa wewnętrznego UE według komunikatu Parlamentu Europejskiego i Rady ${ }^{40}$ „instrumenty i działania muszą opierać się na wspólnych wartościach, do których należą praworządność i poszanowanie praw podstawowych. (...) Wartości i priorytety, na których opiera się strategia bezpieczeństwa wewnętrznego, w tym nasze zaangażowanie na rzecz praw człowieka, demokracji, pokoju i stabilności w naszym sąsiedztwie oraz poza nim, są integralną częścią składową podejścia określonego w europejskiej strategii bezpieczeństwa" ${ }^{41}$. Państwa tworzące Unie Europejską zobligowane są do poszanowania godności każdego człowieka i przestrzegania praw człowieka, celem ich działania jest pokój, środkami strategie bezpieczeństwa.

Ostatnią organizacją $\mathrm{w}$ ramach Europejskiego systemu bezpieczeństwa jest Rada Europy. Najważniejszym dokumentem Rada Europy jest Konwencja o ochronie praw człowieka i podstawowych wolności z 1950 roku $^{42}$. W Preambule określony jest cel Rady Europy jako większa jedność jej członków, a sposobem do jego osiągnięcia ma być ochrona i rozwój praw człowieka i podstawowych wolności. Konwencja chroni prawo do życia już w art. 2: „1 Prawo każdego czło-

38 C. Marcinkowski, Kodeks postępowania w polityczno - militarnych aspektach bezpieczeństwa. Treść, znaczenie, zobowiązania, Warszawa 1996, s. 35.

39 Zob. U. Schürr, Der Aufbau einer europäischen Sicherheits - und Verteidigungsidentität im Beziehungeflecht von EU, WEU, OSZE und NATO, Bonn 2003, s. 149-151

40 Komunikat Parlamentu Europejskiego i Rady z dnia 22 listopada 2010 roku, KOM (2010)673.

41 Ibidem.

42 Dz. U. z 1993 r. Nr 61, poz. 284. 
wieka do życia jest chronione przez ustawę. Nikt nie może być umyślnie pozbawiony życia, wyjąwszy przypadki wykonania wyroku sądowego skazującego za przestępstwo, za które ustawa przewiduje taką karę. 2 Pozbawienie życia nie będzie uznane za sprzeczne $\mathrm{z}$ tym Artykułem, jeżeli nastąpi w wyniku bezwzględnego koniecznego użycia siły: a w obronie jakiejkolwiek osoby przed bezprawną przemocą; b w celu wykonania zgodnego $\mathrm{z}$ prawem zatrzymania lub uniemożliwienia ucieczki osobie pozbawionej wolności zgodnie z prawem; c w działaniach podjętych zgodnie $\mathrm{z}$ prawem $\mathrm{w}$ celu stłumienia zamieszek lub powstania”. Konwencja nakłada na państwa obowiązek ochrony prawa do życia przez właściwe ustawodawstwo krajowe. Jednocześnie formułowane są wyjątki. Dokładnie określono, kiedy prawo do życia jest de facto zawieszane. Zakaz jest wyłączony m.in. w przypadku kary śmierci, i w przypadku wojny domowej.

Do konwencji dołączono Protokoły dodatkowe, Protokół nr z 1983 roku dotyczy zniesienia kary śmierci i w art. 1 stanowi: „Znosi się karę śmierci. Nikt nie może być skazany na taką karę ani nie może nastąpi jej wykonanie”. Kolejny artykuł, nr 2, traktuje o karze śmierci w czasie wojny. „Państwo może przewidzieć w swoich ustawach karę śmierci za czyny popełnione podczas wojny lub w okresie bezpośredniego zagrożenia wojną; kara ta będzie stosowana jedynie w przypadkach przewidzianych przez te ustawy i zgodnie $\mathrm{z}$ ich postanowieniami. Państwo zawiadomi Sekretarza Generalnego Rady Europy o odpowiednich postanowieniach tych ustaw". Prawo do życia jest ograniczone tylko w przypadku czasu wojny, jako możliwość. Państwo może dowolnie z tej możliwości w swoim ustawodawstwie krajowym skorzystać.

Warto wskazać Oświadczenie Rządowe z dnia 29 listopada 2000 r. ${ }^{43}$ w sprawie mocy obowiązującej Protokołu nr 6 do Konwencji o ochronie praw człowieka i podstawowych wolności, dotyczącego zniesienia kary śmierci, sporządzonego w Strasburgu dnia 28 kwietnia 1983 r, podpisane przez Władysław Bartoszewski. Protokół ten wszedł w życie w Polsce 1 listopada 2000 roku. To znaczy, że w RP kara śmierci zostaje utrzymana w czasie wojny za następujące przestępstwa: zdradę, poddanie przez dowódcę wojskowego powierzonej mu placówki, kapitulacja na polu walki złożona przez oficera dowodzącego, wzniecanie lub kierowanie buntem $\mathrm{w}$ armii, przekazywanie tajemnic wojskowych obcemu państwu, szpiegowi lub agentowi, wzniecanie lub kierowanie buntem przez jeńców. Kara śmierci nie jest obligatoryjna ${ }^{44}$. Polska mogła skorzystać z możliwości utrzymania kary śmierci w czasie wojny i z tej możliwości skorzystała, jest to ograniczeniem prawa do życia.

43 Dz. U. z 2001 r. Nr 23, poz. 267.

44 Por. Ibidem. 
W Wilnie 3 maja 2002 powstał kolejny Protokół Dodatkowy do Konwencji, nr 13, dotyczący zniesienia kary śmierci we wszystkich okolicznościach. Nie ma już wyłączeń ze względu na wojnę. „Państwa-Członkowie Rady Europy, sygnatariusze niniejszego Protokołu, przekonane że prawo każdego do życia jest podstawową wartością w społeczeństwie demokratycznym i że zniesienie kary śmierci jest niezbędne dla ochrony tego prawa i pełnego uznania wrodzonej godności każdej z istot ludzkich, zmierzając do wzmocnienia ochrony prawa do życia zagwarantowanego przez Konwencję o Ochronie Praw Człowieka Podstawowych Wolności, podpisaną w Rzymie dnia 4 listopada 1950 r. (zwanej dalej Konwencją), zauważając, że Protokół nr 6, dotyczący zniesienia kary śmierci, podpisany w Strasburgu dnia 28 kwietnia 1983 r. nie wyłącza kary śmierci za czyny popełnione podczas wojny lub w okresie bezpośredniego zagrożenia wojną, zdecydowane podjąć końcowy krok w celu zniesienia kary śmierci we wszystkich okolicznościach, uzgodniły, co następuje: 1 . Znosi się karę śmierci. Nikt nie może by skazany na taką karę, ani nie może nastąpić jej wykonanie. 2. Żadne z postanowień niniejszego Protokołu nie może być uchylone na podstawie Artykułu 15 Konwencji. 3 Niedopuszczalne jest jakiekolwiek zastrzeżenie wobec postanowień niniejszego Protokołu, składane na podstawie Artykulu 57 Konwencji". Zatem kara śmierci jest zniesiona całkowicie, również w czasie wojny. Prawo do życia nie może być ograniczane ani zawieszane nawet w czasie trwania działań zbrojnych.

Rządowy projekt ustawy o ratyfikacji Protokołu nr 13 do Konwencji o ochronie praw człowieka i podstawowych wolności dotyczącego zniesienia kary śmierci we wszystkich okolicznościach, sporządzonego w Wilnie dnia 3 maja 2002 r., „dotyczy umocnienia pozycji Polski na arenie międzynarodowej oraz jej wiarygodności jako państwa stojącego na straży przestrzegania praw człowieka"45. Wpłynął on do Sejmu 16 maja 2013 roku jako druk nr 1409 i 28 maja 2013 roku skierowany został do I czytania w komisjach: 1) Spraw Zagranicznych oraz 2) Sprawiedliwości i Praw Człowieka. Przyszłość pokaże, czy prawo do życia w czasie wojny będzie nieograniczone i niezawieszalne.

\section{ZAKOŃCZENIE}

Przestrzeganie praw człowieka, zwłaszcza w czasie trwania wojny jest niewystarczające, w powszechnej opinii, zwłaszcza w opinii środków masowego przekazu, przepisy, zasady i dobre tradycje istnieją na poziomie normatywnym i społecznym. I to nie one są problemem nieprzestrzegania praw człowieka. Bra-

45 http://www.sejm.gov.pl/Sejm7.nsf/PrzebiegProc.xsp?nr=1409, (16.06.2013 r.). 
kuje wyciągania konsekwencji z czynów tych, którzy je łamią i ponoszenia odpowiedzialności przez nich. A w przekonaniu autorki niniejszego artykułu przeszkodą są też przepisy, które dopuszczają zawieszenie czy ograniczenie praw. W społeczności międzynarodowej, gdzie różnie jest rozumiane życie, jego temporalne i morfologiczne granice trudno aby bezwzględnie przestrzegać praw człowieka.

Życie jest wielką wartością. Jedni świadomie i dobrowolnie godzą się ryzykować, poświęcać, wpisując ryzyko śmierci w swoją profesję żołnierską. Inni nie chcą a muszą je ryzykować i poświęcać, choć są cywilami, bo prawo międzynarodowe jest słabo przestrzegane a wojna rozumiana po clausewitzowsku.

Za najtrafniejszą definicję wojny przyjmuje się powszechnie definicję niemieckiego (właściwie pruskiego) generała i teoretyka wojny - Carla von Clausewitza, który określił w XVIII wieku wojnę jako „kontynuację polityki przy użyciu środków przemocy, w celu osiągnięcia celów politycznych, gospodarczych, ideologicznych lub ekonomicznych" ${ }^{46}$. Dziś na tę definicję powołują się encyklopedie, leksykony, słowniki na całym świecie, w różnych kulturach prawnych ${ }^{47}$. Tu brak miejsca na prawa człowieka.

Jest jeszcze definicja Jana Pawła II: „Wojna nigdy nie jest metodą taką samą jak inne, którą można się dowolnie posługiwać, aby rozstrzygać spory między państwami. Jak przypomina Karta Narodów Zjednoczonych i prawo międzynarodowe, nawet gdy chodzi o obronę dobra wspólnego można się do niej uciec jedynie w sytuacji zupełnej ostateczności, zachowując przy tym ściśle określone warunki i biorąc pod uwagę jej konsekwencje dla ludności cywilnej w czasie działań wojennych i po ich zakończeniu."

Obydwie definicje mówią o wojnie, ale tylko ta druga respektuje w wojnie prawa człowieka w czasie wojny. Wśród teoretyków, naukowców, zwłaszcza etyków, a nawet prawników zdobyła definicja Jana Pawła duże uznanie, ale na grunt praktyki nie przeszła. Żołnierze (w wielu państwach świata, w naszym też) dalej są szkoleni wedle wskazań Clausewitza. Aktualne działania wojenne na świecie pokazują jak żywotna jest ta definicja i jak mało skuteczna jest ochrona praw człowieka w czasie konfliktu zbrojnego. Wystarczy włączyć wiadomości, aby uzyskać informacje na ten temat, nie potrzeba prowadzić badań empirycznych.

Owe badania przydały by się jednak, aby móc ukarać państwa, które łamią prawa człowieka. Niestety społeczność międzynarodowa najwyraźniej nie jest tym zainteresowana. My, Polacy mamy tendencje, aby uważać, że problem wojny

46 Definicja pochodzi z dzieła Vom Kriege.

47 Tak np. W. Czopek (red.), Popularna Encyklopedia Powszechna, Warszawa 2003, t. 12 , s. 277. 
nas nie dotyczy. Uważamy, że w Polsce praw człowieka są przestrzegane, obydwa twierdzenia nie są do końca prawdziwe.

Współczesne środki masowego przekazu dość często podejmują tematy bioetyczne, prawno - etyczne, dyskusje na temat zasadności kary śmierci wracają przy okazji różnych kampanii wyborczych. Wielu polityków twierdzi, że Polska jest krajem, w którego systemie karnym nie ma kary śmierci, nie zauważając, że ona jest, w czasie wojny. Dopiero trwają prace nad usunięciem jej z katalogu kar. Przyszłość pokaże jak się one zakończą, oby do tego czasu Polska nie prowadziła wojny.

\section{DIE MENSCHENRECHTE IN DER KRIEGSZEIT}

Es war 5559 Kriege vom Summerzeiten bis zum zweite Weltkrieg, Nach 1945 etwa 160 Kriege. Was ist der Krieg eigentlich? Es ist ein Zustand, in dem die Staaten gegeneinander kämpfen und keine friedliche Beziehungen zusamen haben. Es ist hier wichtig ius ad bellum (also die Staat hat Recht um Krieg zu führen. Heute Krieg ist verboten, es sind nur zwei Möglichkeiten, die Selbstverteidigungskrieg und militärische Aktion auf Initiative des UN - Sicherheitsrates) und ius in bello (Internationale humanitären Völkerrechts, hier wichtig sind Menschenrecht. Hauptmenschenrecht ist das Recht auf Leben, lebende Menschen haben Rechte).

Es sind Grundsätze des humanitären Völkerrechts, aber nicht immer sind beobachtet. Wir haben 4 verschiedene Systeme zum Schutz der Menschenrechte, für Polen besonders interessant ist Europäisches und Internes System. In Polen mit Recht auf Leben ist nur ein Problem, während des Krieges haben wir Todesstrafe.

Der Krieg respektiert Menschenrechte nicht oft. 